\title{
H. Michael Shepard, Dennis J. Slamon, and Axel Ullrich honored with the 2019 Lasker DeBakey Clinical Medical Research Award
}

$\mathbf{T}$

he characterization of tumor-specific proteins and genes has led to the development of several targeted therapies that have improved and extended the lives of patients with a variety of cancers. The 2019 Lasker DeBakey Clinical Medical Research Award recognizes H. Michael Shepard, Dennis J. Slamon, and Axel Ullrich (Figure 1) for their contributions to the development of the HER2-targeting monoclonal antibody (mAb), Herceptin (also known as trastuzumab), the first of its kind to effectively target a cancerassociated protein and increase survival of women with HER2 ${ }^{+}$breast cancer.

\section{The hunt for cancer-causing genes and therapeutic strategies}

Unlike normal cells, cancer cells are able to grow uncontrollably and avoid activation of cell death pathways. Researchers and clinicians have long focused on understanding the origin of these cells and identifying potential therapies to curb growth and spread of these cells. In the 1970s, several advances were made toward unraveling the origins of cancer and identifying cancer-killing molecules. In 1976, Brown, Varmus, and colleagues provided the first evidence that cancer-causing genes (oncogenes) are present within the genome of normal cells (1). Around the same time, a team lead by Lloyd Old revealed that endotoxin-treated cells release a substance, TNF, that is capable of killing tumor cells (2). Moreover, in a mouse model, injection of TNF-containing supernatant from endotoxin-treated macrophages was able to shrink tumors without killing the mouse. The cancer-specific nature of TNF led many different groups and biotech companies to begin programs aimed toward developing TNF as a cancer therapeutic; among these was Genentech, which was founded in 1976 by Robert Swanson and Herbert Boyer in San Francisco.

H. Michael Shepard joined Genentech after completing graduate training with George Malacinski and postdoctoral training with Barry Polisky at Indiana University at Bloomington. Polisky was a recent recruit to Indiana from UCSF, and under his tutelage, Shepard worked out mechanisms by which plasmid copy number is regulated by E. coli and was introduced to several luminaries at UCSF. As Shepard recently recounted to the JCI, "I interviewed at a number of places, and it seemed clear to me that the most dedicated science, was actually being done at Genentech, so I decided to go there." Shepard initially worked with David Goeddel, who is best known for cloning human insulin, growth hormones, and many of Genentech's early products. Eventually, Shepard moved over to the Pharmacology Department and became interested in generating medicines that were not just cloned genes. Shepard became part of Genentech's TNF project, which took off when they obtained tumor cell lines from the ATCC. "We looked at about 100 different tumor cell lines and asked whether or not they were sensitive to killing by TNF. More than two-thirds of these cells were already resistant" (3). The revelation that so many tumor cells were resistant to TNF initiated studies to better understand the factors that drive this resistance.

While Shepard was looking to unravel the mechanisms underlying TNF resistance, Axel Ullrich, also at Genentech, was exploring the link between growth factors and cancer. In particular, Ullrich was interested in growth factor receptors, and in 1985, Ullrich and colleagues reported the identification of a human gene with homology to the chicken oncogene $v$-erbB and EGF1, which they named human EGF 

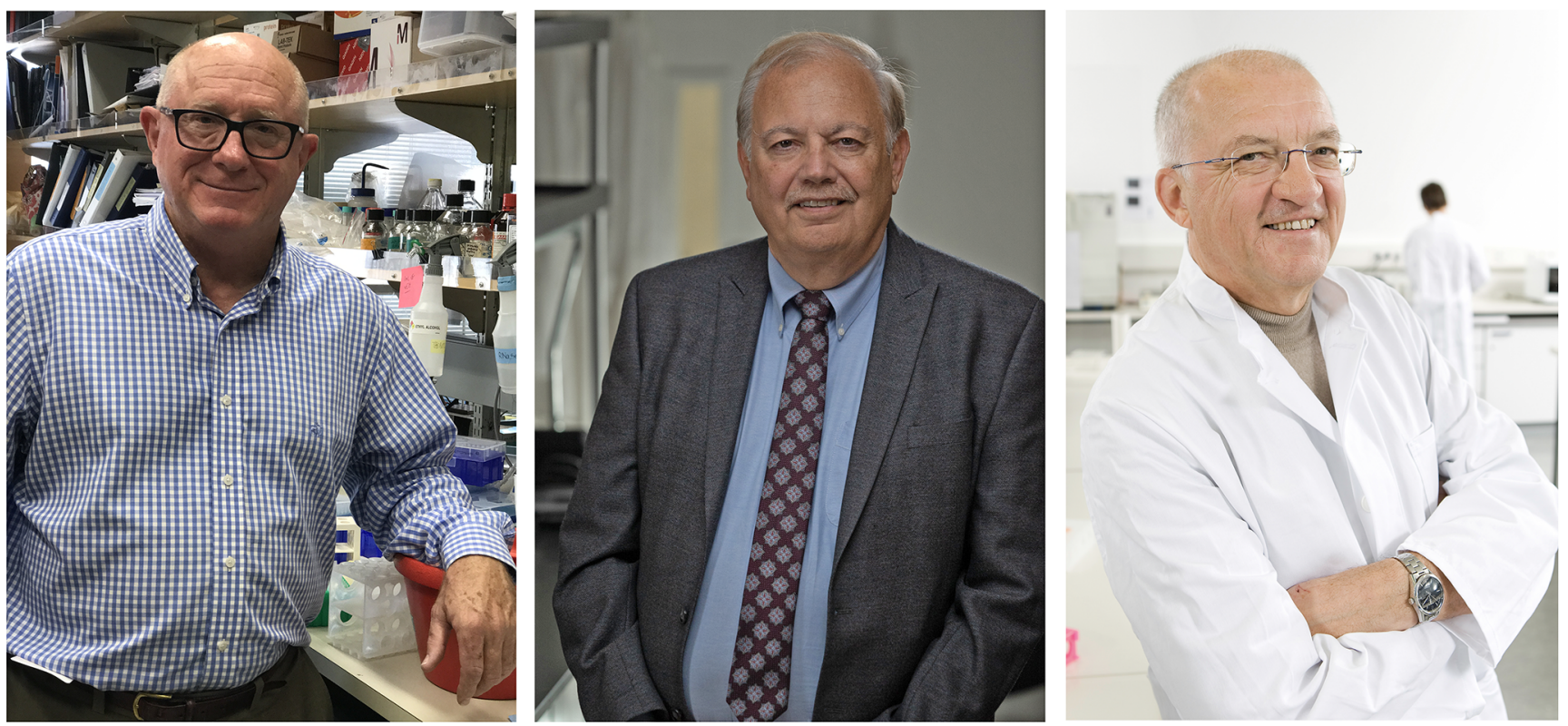

Figure 1. The recipients of the 2019 Lasker DeBakey Clinical Medical Research Award. H. Michael Shepard, Dennis Slamon, and Axel Ullrich are being recognized for their work toward the development of Herceptin, the first targeted-mAb therapy for cancer. Photo of Axel Ullrich courtesy of the Mary and Albert Lasker Foundation.

ty training, with the intention of returning to Chicago; however, as Slamon recently recounted to the JCI, "At the end of my fellowship, I starting to study some of these cancer-associated genes, which were then evolving at the time as these oncogenes or growth-regulating genes, and the work kept getting more and more exciting." At UCLA, Slamon and his team evaluated expression of oncogenes in fresh human tumors and adjacent normal tissue and demonstrated that oncogenes are differentially expressed in normal and tumor tissues and that oncogenes were variably expressed between tumor types (10). After hearing about Ullrich's interest in growth-regulating genes, Slamon approached Ullrich about collaborating to evaluate the expression of the growth factors and oncogenes identified by Ullrich's group in Slamon's collection of human tumors. As Slamon recalls, "Basically, he sent us some probes and we started to screen our tumor banks. We were keeping a fairly open mind and were going through a number of different tumors, colorectal cancer, lung cancer, gastric cancer, etc. ... When we got to the breast panel, we found that HER2 gave us a very striking signal. In about $25 \%$ of the breast tumor cohort, there was this huge increase in signal intensity. The only problem was that we had no long-term follow-up on the patients whose samples were used in the initial identification this alteration in breast cancer." Slamon went to his colleague, Bill McGuire at the University of Texas, San Antonio, who had breast cancer samples with patient follow-up data. Analysis of these samples revealed that HER2 expression correlated with early relapse and much shorter survival (11).

\section{A target in their sights}

With the demonstration of HER2 as marker of aggressive breast cancer, the Genentech team moved to generate a HER2-targeting $\mathrm{mAb}$ by immunizing mice with HER2-expressing cells. Hudziak and Shepard found that one mAb, 4D5, inhibited growth of HER2-overexpressing cancer cells and restored TNF sensitivity (12). Around this time, Ullrich left Genentech to take a position at the Max Planck Institute, leaving Shepard to spearhead the project at the company. According to both Shepard and Slamon, there was reluctance at Genentech to pursue the development of a mAb-based therapy. However, Shepard was persistent and finally given funding and an opportunity to continue the work toward developing a HER2-specific antibody due to the support of then Genentech Vice President, Bill Young. After a set of unpublished experiments, in collabora- tion with Slamon, that showed the mouse $\mathrm{mAb}$ was able to localize to and specifically target HER $2^{+}$tumors in patients, the next step was to develop a humanized version of the 45D mAb. Paul Carter, an antibody engineer at Genentech, was brought on board the HER2 project to convert the murine antibody into a humanized version that could be repeatedly administrated to patients, unlike the murine mAb. Carter had invented a method called "six-pack mutagenesis" with which he could humanize both the heavy and light chains of the mouse antibody in one reaction, and make numerous variants at the same time. One of the variants that Carter designed, humAb4D5-8, stood out among the rest, with a high affinity for HER2 and the ability to block proliferation of breast cancer cells expressing high levels of HER2 (13). This antibody would be the precursor and basis for Herceptin (trastuzumab).

\section{Herceptin goes to trial}

The early clinical trials of Herceptin were led by Slamon and conducted at UCLA. These trials indicated that Herceptin was well tolerated, and, at higher doses, potentially efficacious. As recounted by Slamon, "The initial phase one studies were done here at UCLA on a small group of women who were given really low doses of the anti- 
body. Those women deserve a lot of credit for all the success we've had, because we had to start at doses that were basically less than we were giving a mouse. Genentech and we were worried about safety, so we had to go slowly, but ultimately, we went to the next cohort and upped the dose, until we reached a dose where essentially all the receptors in the body were saturated and we started to see efficacy. In fact, the longest living survivor ever treated was part of those phase 1B studies at UCLA. She had multiple metastatic lesions throughout her lungs on her lymph nodes and had failed all of our traditional chemotherapy and hormonal therapy after surgery. She went into a complete remission after just nine weeks of treatment and has remained in remission for the last 30 years." The success of these initial studies paved the way for larger trials, which revealed that Herceptin in combination with standard chemotherapy agents, such as paclitaxel, markedly expanded time to disease progression, increased response duration, and extended survival times for women with HER2 ${ }^{+}$ breast cancer (14). Herceptin is now part of the standard therapy for HER2 ${ }^{+}$breast cancer, and is currently one of many mAbs that are FDA approved for treating cancer. It is also on the World Health Organization's list of Essential Medicines.
The success of Herceptin has paved the way for the development of other tumor-specific therapeutics and truly changed the way cancer treatment is approached. This year's Lasker DeBakey Clinical Medical Research Award honors the dedication and collaboration of H. Michael Shepard, Dennis Slamon, and Axel Ullrich that not only paved the way for the development of Herceptin but also laid the groundwork for the development of other targeted therapies for the treatment of cancer and other diseases.

\section{Corinne L. Williams}

1. Stehelin D, Varmus HE, Bishop JM, Vogt PK. DNA related to the transforming gene(s) of avian sarcoma viruses is present in normal avian DNA. Nature. 1976;260(5547):170-173.

2. Carswell EA, Old LJ, Kassel RL, Green S, Fiore $\mathrm{N}$, Williamson B. An endotoxin-induced serum factor that causes necrosis of tumors. Proc Natl Acad Sci U S A. 1975;72(9):3666-3670.

3. Sugarman BJ, Aggarwal BB, Hass PE, Figari IS, Palladino MA, Shepard HM. Recombinant human tumor necrosis factor-alpha: effects on proliferation of normal and transformed cells in vitro. Science. 1985;230(4728):943-945.

4. Coussens L, et al. Tyrosine kinase receptor with extensive homology to EGF receptor shares chromosomal location with neu oncogene. Science. 1985;230(4730):1132-1139.

5. Schechter AL, et al. The neu oncogene: an erb-B-related gene encoding a 185,000-Mr tumour antigen. Nature. 1984;312(5994):513-516.

6. King CR, Kraus MH, Aaronson SA. Amplification of a novel v-erbB-related gene in a human mammary carcinoma. Science. 1985;229(4717):974-976.

7. Yamamoto T, et al. Similarity of protein encoded by the human c-erb-B-2 gene to epidermal growth factor receptor. Nature. 1986;319(6050):230-234.

8. Sugarman BJ, Lewis GD, Eessalu TE, Aggarwal BB, Shepard HM. Effects of growth factors on the antiproliferative activity of tumor necrosis factors. Cancer Res. 1987;47(3):780-786.

9. Hudziak RM, Schlessinger J, Ullrich A. Increased expression of the putative growth factor receptor p185HER2 causes transformation and tumorigenesis of NIH 3T3 cells. Proc Natl Acad Sci US A. 1987;84(20):7159-7163.

10. Slamon DJ, deKernion JB, Verma IM, Cline MJ. Expression of cellular oncogenes in human malignancies. Science. 1984;224(4646):256-262.

11. Slamon DJ, Clark GM, Wong SG, Levin WJ, Ullrich A, McGuire WL. Human breast cancer: correlation of relapse and survival with amplification of the HER-2/neu oncogene. Science. 1987;235(4785):177-182.

12. Hudziak RM, Lewis GD, Winget M, Fendly BM, Shepard HM, Ullrich A. p185HER2 monoclonal antibody has antiproliferative effects in vitro and sensitizes human breast tumor cells to tumor necrosis factor. Mol Cell Biol. 1989;9(3):1165-1172.

13. Carter P, et al. Humanization of an antip185HER2 antibody for human cancer therapy. Proc Natl Acad Sci U S A. 1992;89(10):4285-4289.

14. Slamon DJ, et al. Use of chemotherapy plus a monoclonal antibody against HER2 for metastatic breast cancer that overexpresses HER2. N Engl JMed. 2001;344(11):783-792. 